\title{
El erotismo de la lectura académica. Amor y filología en "Mimnermos: The Brainsex Paintings" de Anne Carson ${ }^{1}$
}

\section{Silvia JIMÉNEZ BARBA \\ Universidad Nacional Autónoma de México}

\begin{abstract}
En "Mimnermos: The Brainsex Paintings", Anne Carson ilustra el enamoramiento que un académico siente por su objeto de estudio; es una relación amorosa con el autor. Consta de tres partes: la primera son fragmentos de Mimnermo, poeta lírico arcaico griego del siglo VII. La segunda parte es un ensayo, donde se explora el tema principal del lírico griego: el tiempo y su postergación por medio del hedonismo. La tercera es una entrevista al poeta. En las tres partes, Carson retrata tres maneras en las que un lector profesional se relaciona con el texto que lee. El poema en conjunto es una especie de tríptico literario, cada parte refleja un proceso de lectura distinto. Es el retrato del deseo erótico que puede existir entre el lector y la obra que está leyendo.
\end{abstract}

Palabras Clave: Anne Carson, Mimnermo, lectura, hedonismo literario, filología clásica y posmodernismo.

In "Mimnermos: The Brainsex Paintings", Ann Carson illustrates how academic readers fall in love with their subjects. An intimate relationship with the author. It is divided in three parts: the first one presents fragments from Mimnermos, an archaic Greek lyric poet from the seventh century. The second part is an essay, in which Carson explores the poet's preferred themes: time and hedonism. The third is an interview featuring Mimnermos. The poem as a whole is a literary triptych, each part representing different ways of reading. It is the portrait of the erotic love that occurs between reader and writer.

KEYWORDS: Anne Carson, Mimnermos, reading, literary hedonism, classical philology and postmodernism.

\begin{abstract}
Whenever I look into Plotinus I feel always all the old trembling fevered longing: it seems to me that I must be born for him, and that somehow someday I must have nobly translated him: my heart, untraveled, still to Plotinus turns and drags at each remove a lengthening chain. It seems to me that him alone of authors I understand by inborn sight...
\end{abstract}

Stephen MacKenna

\footnotetext{
${ }^{1}$ El siguiente artículo es una reelaboración de algunos capítulos de la tesis de maestría que presenté para obtener el grado de Maestría en Traducción en el Colegio de México en enero 2017, titulada Una erótica de la traducción. "Mimnermos: The Brainsex Paintings" de Anne Carson. Traducción comentada.
} 


\section{$156 \square$ EL EROTISMO DE LA LECTURA ACADÉMICA. AMOR Y FILOLOGÍA}

Elegir una obra o autor para un estudio académico debe justificarse con mayor precisión y elegancia que un simple gusto por el texto, a pesar de que siempre, o la mayoría de las veces, la primera razón que nos impulsa a hacer un trabajo largo e intenso es que simple y sencillamente nos gusta la obra. En su poema "Mimnermos: The Brainsex Paintings", la poeta y clasicista Anne Carson ilustra el enamoramiento que un académico siente por su objeto de estudio; es el retrato del deseo erótico que puede existir entre el lector y la obra que está leyendo, deseo que se convierte en una relación amorosa con el autor.

El poema de Carson fue publicado en 1980, en Plainwater (Carson, 1995) donde se reúnen otras obras. Consta de tres partes: la primera son fragmentos de Mimnermo, un poeta lírico arcaico griego del siglo VII, del cual no se sabe mucho más que su lugar de origen y los aproximadamente ochenta versos que de él sobreviven. Los fragmentos en inglés sólo mantienen un eco distante del original griego. La segunda parte es un ensayo, "Mimnermos and the Motions of Hedonism", donde se explora el tema principal del lírico griego: el tiempo y su postergación por medio del hedonismo. La tercera es una entrevista al poeta, para la cual Anne Carson realiza un viaje literario por el tiempo. En las tres partes, aunque parecen distantes en forma y fondo, Carson retrata tres maneras en las que un lector profesional se relaciona con el texto que lee. El poema en conjunto es una especie de tríptico literario, cada parte refleja una escena diferente, un proceso de lectura distinto.

Individualmente veremos cómo cada sección nos deja con alguna insatisfacción particular. Pero tomada en conjunto, sólo al contemplar y ojear The Brainsex Paintings nos abrumamos por la complejidad de las formas: traducción, que exige una lectura detallada y un estado de ánimo serio; un ensayo, que pensamos nos podrá explicar los poemas, y una entrevista de ultratumba, una nekkya o katábasis (viaje al inframundo, al estilo de Odiseo y Eneas) para conocer al poeta. Nos esforzamos por entender qué es lo que une estas partes y si en verdad están unidas.

La relación erótica entre un texto y los lectores es un asunto que le inquieta a Anne Carson. En Eros the Bittersweet, título que adquirió su tesis doctoral al ser publicada, trata el erotismo y los orígenes de la literatura griega. Ella encuentra una semejanza entre el amor y el discurso porque ambos están hechos de espacios y distancias, edges los llama ella y lo expresa así: "What is erotic about reading (or writing) is the play of imagination called forth in the space between you and your object of knowledge. Poets and novelists, like lovers, touch that space to life with their metaphors and subterfuges"(1998: 209). Para esta poeta, el erotismo es algo inherente a la literatura y forma parte de la experiencia lectora. Veamos la siguiente cita:

Think how it feels. As you read the novel your mind shifts from the level of characters, episodes and clues to the level of ideas, solutions, exegesis. The activity is delightful, but also one of pain. Each shift is accompanied by a sharp sense that something is being lost, or has already been lost. Exegesis mars and disrupts sure absorption in the narrative. The narrative insists on distracting your attention from exegesis. Yet your 
mind is unwilling to let go of either level of activity, and remains arrested at a point of stereoscopy between the two. They compose one meaning. The novelist who constructs this moment of emotional and cognitive interception is making love, and you are the object of his wooing (Carson, 1998: 90).

Lo erótico en la literatura se encuentra entre el lector y el texto. Hay una seducción entre el poeta y el receptor, quien debe interpretar las palabras de su amado como pueda. En "Mimnermos: The Brainsex Paintings", Carson intenta acercarse a su objeto amoroso de tres maneras diferentes, todas con una larga tradición literaria, tratando de acortar la distancia que separa a una amante de su amado, que son ella misma y Mimnermo, por medio de los diferentes procesos de lectura/escritura que se pueden hacer. Pero desde luego, la intimidad entre ambos sólo puede ser intelectual, sólo puede haber sexo mental.

El primer retrato está hecho en verso. La relación sexomental es la de un texto meta con el original. La presentación del texto es la siguiente: primero está la palabra fragmento abreviada, seguido del número de fragmento según corresponde a la edición crítica de Diehls, después un título. Recordemos que entre los antiguos poner un título a los poemas no era una convención usual; cuando alguna edición los titula, suele tomarse del primer verso del poema, como sucede aquí. Después del título hay una glosa, una breve nota que resume alguna impresión relevante que tuvo la lectora. Finalmente, el poema dispuesto en dísticos. Veamos (Carson, 1995: 3):

fr. 1

What Is Life Without Aphrodite?

He seems an irrepressible hedonist as he asks his leading question

Up to your honeybasket hilts in her ore-or else

Death? for yes

how gentle it is to go swimming inside her the secret swimming

Of men and women but (no) then

the night hide toughens over it (no) then bandages

Crusted with old man smell (no) then

bowl gone black nor bud nor boys nor women nor sun no

Spores (no) at (no) all when

God nor hardstrut nothingness close

its fist on you.

El poema no es una traducción de Mimnermo, tiene una dicción y estética ajena a la poesía antigua. Es sólo en los títulos donde vemos algo de él. Podemos decir que es lo que queda del poeta una vez que los puntos de encuentro y distancia fueron retratados por Anne Carson. La poeta decide no traducir ella misma el primer verso introductorio, simplemente lo toma de la traducción de lírica arcaica publicada por Loeb (Campbell, 
1990), un sello de ediciones clásicas ejemplarmente académico. He aquí esta versión para comprobar la diferencia entre ambas:

What life is there, what pleasure without golden Aphrodite? May I die when I no longer care about secret intrigues, persuasive gifts, and the bed, those blossoms of youth that men and women find alluring. But when painful old age comes on, which makes even a handsome man ugly, grievous cares wear away his heart and he derives no joy from looking upon the sunlight; he is hateful to boys and women hold him in no honour. So harsh has the god made old age (91).

La disposición textual, es decir, el retrato que Carson está pintando, es un comentario sobre las traducciones académicas que suelen hacerse dentro de los estudios clásicos, por eso los títulos están en un lenguaje arcaizante, porque ese tipo de traducciones son las que un verdadero filólogo clásico debe hacer. Ésas sí son traducciones, no lo que Carson hace. También por eso los versos están en dísticos, porque la poesía elegíaca se escribía en dísticos elegíacos: un hexámetro seguido de un pentámetro. En inglés la regularidad métrica sólo es aparente mas no real. Es interesante que el primer retrato que haya decidido ilustrar, que la primera forma de plasmar el enamoramiento sea con la traducción. Esto es, en parte, debido a su formación en la filología clásica, pues el primer acercamiento meticuloso de un filólogo al texto es por medio de un análisis gramatical profundo y de la traducción. Ella está consciente de cuánto necesita la traducción para asimilar la carga semántica de las palabras.

Es notorio que el grado de creatividad o alejamiento con respecto al "texto fuente" varía de fragmento en fragmento. La creación de neologismos y la sintaxis rota ajena al inglés son también una reproducción de la lectura que experimentó el lector del griego. Es como si en esta sección Carson se propusiera traducir la forma, la apariencia, el efecto y la sensación del griego, pero no las palabras. Es desconcertante leer algo que parece traducción, pero que también es evidente que no lo es.

El segundo retrato se intitula "Mimnermos and the Motions of Hedonism". La técnica es prosa, a primera vista un ensayo literario sobre la poesía de Mimnermo de Colofón; sin embargo, es difícil definir qué tipo de ensayo es, pues al carecer de notas pareciera que más bien es un ensayo literario, pero al citar fragmentos y frases en específico, parece que Carson no deja de lado su formación filológica. En esta parte explica su lectura del texto fuente, qué es lo que ella ve en sus fragmentos y no en qué la hacen pensar. También hace exégesis e informa a su lector del tema principal de la elegía que está estudiando: el tiempo y las distracciones hedonísticas previas a la muerte. Cuando alude a éste, no toma la cita de sus versiones sino del original griego. Es como si la primera parte, el primer retrato, no existiera. Esto nos alerta sobre la autonomía que existe entre los tres géneros de la obra.

Además de la traducción, hacer un ensayo crítico es otra forma de "descifrar" a los clásicos grecolatinos. Si la primera sección de esta obra tripartita es un intento de Carson por aprehender a Mimnermo, en "The Motions of Hedonism" retrata el conte- 
nido poético de la obra del lírico griego. Este ensayo es otra manera de asir a los clásicos que parte de la formación filológica de Anne Carson y que refleja, y a la vez rechaza, los acercamientos más académicos a la comprensión de la poesía. Ella usa la prosa como recurso poético y la poesía como recurso pictórico y cómo su proceder le permite expresar la distancia temporal que separa a un autor de su lector.

El único elemento que hace sospechar de la seriedad de este texto como ensayo académico es la abundancia de metáforas, puesto que ella explica los fragmentos con medios poéticos. Con las metáforas, Anne Carson traza los bordes que separan y alejan al amante y al amado literario. Son también las armas de seducción e interpretación de la poeta. El efecto es además sorpresivo, pues después de la dificultad de los poemas, pensamos que el ensayo y la prosa no sólo serán más sencillos de leer, sino que explicarán la primera parte. Pero, como ya vimos, no hay conexión entre estas partes, sino ruptura.

El lector del ensayo obtendrá una experiencia similar a la de ver un cuadro, cual mimesis de una acción que pasa en la mente de Carson. Así pues, ella describe su lectura de los fragmentos originales de Mimnermo. En esta parte es sólo Mimnermo, es su retrato, no hay nada de ella más que las palabras que usa para describirlo a él; el poeta griego al desnudo, el amado descifrado por la amante. Lo que distingue el segundo retrato de los otros dos, es que aquí hay perspectiva, la cual se puede definir como una técnica visual que retrata el mundo como una estructura objetiva que se representará con fidelidad por métodos racionales (Tschofen, 2013: 235). El elemento pictórico se aprecia, por ejemplo, en las siguientes frases:

1) we see the windows glow in turn with boys and flesh and dawn and women and the blue lips of ocean. It is true he likes to get the sun into every poem (12).

2) Time goes whorling through landscapes and human lives bent on its agenda, endlessly making an end of things. You have seen this vibration of time in van Gogh, moving inside color energy. It moves in circles (not lines) that expand with a kind of biological inevitability, like Mimnermos's recurrent metaphor of the youth of humans as a flowering plant or fruit (12).

3) Sun is the only pulse that runs but itself. While transiency grasps the rest of us through and through, Helios rides it as a cup across the sky (13).

4) También en su traducción de floruit: "He came to flower" (13).

En pocas palabras, describe los poemas como si fueran pinturas, lo cual haría de este ensayo una especie de écfrasis de los fragmentos griegos. La écfrasis consiste en recrear o volver a presentar una obra artística ya representada anteriormente; es la mímesis de la mímesis (O’Dogherty: 2011: 8). Carson, consciente de la obsesión por la mímesis entre los teóricos antiguos (Carson, 1990: 145), crea una transposición de representaciones con la pintura como leitmotiv, lo cual tiene implicaciones para la comprensión de este segundo retrato sexomental y de toda la obra.

La poesía y la pintura son instrumentos que de alguna manera traspasan las limitaciones del tiempo, el entonces y el ahora, como dice Carson, o "a needle stitching 
together the two moments that compose nostalgia"(1995: 14). Es también pertinente recordar que algunos teóricos conciben la écfrasis como una figura relacionada con la inmovilidad: por ejemplo, para Murray Krieger y Wendy Steiner esta figura retórica es una forma de "congelar el tiempo en el espacio" (O’Dogherty, 2011: 22-23). Nuevamente parece una manera muy orgánica de unir la forma con el contenido, de hacer poética una de las principales preocupaciones de este lírico arcaico, pues según nos dice Carson y según lo podemos apreciar al leer a Mimnermo, el hedonismo para él es una forma de marcar el tiempo ${ }^{2}$ y su progreso hacia la muerte. ${ }^{3}$ Así pues, estos retratos sexomentales son el intento de Anne Carson por unirse mental y temporalmente al poeta que estudia. Asimismo, el ensayo está introducido por un epígrafe que habla sobre el contenido temático del mismo:

I can swim like the others only I have a better memory than the others, I have not forgotten my former inability to swim. But since I have not forgotten it my ability to swim is of no avail and I cannot swim after all.

Quizá la idea no sea clara, pero estas palabras de Kafka sirven para explicar que el tiempo es negación, ${ }^{4}$ que el movimiento temporal continuo imposibilita la estabilidad y el conocimiento.

${ }^{2}$ Es interesante cómo el tema del tiempo puede estar relacionado con la naturaleza del género lírico, y es sobre todo pertinente en el caso de Mimnermo, cuya poesía lírica fue de las primeras en ser escritas. Al respecto: "Another approach is defining lyric in terms of its relationship to time. The claim that it rejects or ignores temporality, though common, is less persuasive than more subtle attempts to anatomize the complex and varied ways the lyric engages with time. Thus, for example, Sharon Cameron's trenchant study Lyric Time: Dickinson and the Limits of Genre suggests that the mode in question fears time, associating it with death, and works out ways of redefining that potential antagonist. But how does this imputed fear relate to the indubitable presence of history in many lyrics?" (Dubrow, 2014: 114).

${ }^{3}$ Por ejemplo, en sus fragmentos Mimnermo utiliza todos los motivos tradicionales para hablar del tiempo que la académica Helen Vendler explica son lugares comunes en la literatura universal: "When poets describe Time, they tend to employ many of the images of passing time that have entered cultural memory - such motifs as the waves of the sea, the progress of the sun from dawn to dusk, the fall of great men, the tragedy of early death" (1997: 13).

${ }^{4} \mathrm{He}$ aquí una lectura interesante del epígrafe: "Something that cannot logically be different in the same aspect at the same time can only suggest a time in which self-identical states are successively left behind, such that aspects do not conflict, but instead alter. Logic and 'our concept of time' are in league together. Aristotle thinks this is true not only of natural entities that develop, but also of intellectual faculties that learn. One only knows after one does not know, never before, and one is never ignorant and knowing at the same time. Kafka takes issue with the inner contract between logic and time" (North, 2015: 163). Otra lectura posible es la siguiente: "For Kafka, German is a language of literary expression-but a particular German. In this way, Kafka defines the impasse barrier access to writing for the Jews of Prague and making their literature into something impossible: the impossibility of not writing, the impossibility of writing in German, the impossibility of writing otherwise. Kafka had to literally express his alterity and foreigness using the dominant language" (Dosse, 2010: 243). Esta idea podría explicar por qué Carson rehace los poemas de Mimnermo, por la imposibilidad de leer, por la cercanía y a la vez lejanía que siente con el griego antiguo, y porque la traducción, 
"The Mimnermos Interviews" es la tercera y última parte de este opúsculo. Como las partes que le anteceden, es el retrato de una relación sexomental, pero en este caso la técnica es la dramaturgia, en general es más difícil de encasillar dentro de un género literario. Podemos pensar, primeramente, que es sólo una entrevista periodística y, sin duda, formalmente es a lo que más se parece. Es como si Anne Carson hubiera agotado las formas convencionales y académicas en su ansiedad por conocerlo, o más bien por llenar los espacios que los textos dejan y ya sólo encontrara la satisfacción amorosa con una conversación imaginaria.

Veamos el título. El que Mimnermo esté funcionando como adjetivo ("The Mimnermos Interviews") hace que parezca una entrevista a alguien famoso, a una estrella de rock, por ejemplo, más que a un poeta del siglo vII, lo cual demuestra con un dejo de ironía en qué estima tiene la autora al poeta.

La puntuación que utiliza Carson a lo largo de toda la obra es particular, sobre todo en los poemas, lo cual se explica porque están en verso libre y los signos de puntuación podrían afectar los patrones de lectura. En esta sección son totalmente inexistentes. Como en el griego y como en Mimnermo, el lector tiene que hacer un trabajo de interpretación parecido al de un filólogo al leer un papiro con escritura seguida, como sucede casi al final de la entrevista 3 :

M: I'm not angry I am a liar only now I begin to understand what my dishonesty is what abhorrence is the closer I get there is no hope for a person of my sort I can't give you facts I can't distill my history into this or that home truth and go plunging ahead composing miniature versions of the cosmos to fill the slots in your question and answer period it's not that I don't know there is an act of interpretation demanded now by which we could all move to the limits of the logic inherent in this activity and peer over the edge but everytime I everytime you see I would have to tell the whole story all over again or else lie so I just lie who are they who are the storytellers who can put an end to stories (25).

Es difícil distinguir cuándo empieza y termina una frase o un sintagma. Generalmente en inglés la entonación nos puede ayudar en estas circunstancias, pero la falta de puntuación complica la lectura al provocar que el lector tenga que detenerse y pensar qué va con qué.

No es sólo en este aspecto que Carson acerca al lector a Mimnermo. Los "personajes" de las entrevistas son "M" e "I"; el último presumiblemente es Interviewer, pero también podría ser el pronombre personal de la primera persona: Yo. Sumergirse en un texto de tal manera que las identidades se confundan es un efecto propio de la lírica, indicio de que las entrevistas también forman parte del lenguaje poético de la obra:

La fuerza ilocutiva de una poesía es siempre una invitación al lector a que asuma el mensaje como propio. Esta relación pragmática y, por lo tanto, semiótica parece fun- 


\section{$162 \square$ EL EROTISMO DE LA LECTURA ACADÉMICA. AMOR Y FILOLOGÍA}

damental. Sólo por ella se explica el relieve del lector en la comunicación lírica; el poeta quiere que el lector incorpore la significación y el sentido del poema; pero el lector sólo puede hacerlo parcial o imperfectamente (Lázaro Carreter, 1990: 22).

También Roman Ingarden comparte esta idea: "El lector, en cuanto sujeto psicológico particular, no sólo debe identificarse con el yo lírico que se expresa en el poema; debe sentirse por un momento como si fuera tal yo, experimentando y expresando lo mismo que el lírico; debe hacerse el yo lírico fictivo" (Lázaro Carreter, 1990: 46). En las entrevistas, Anne Carson está dramatizando esta experiencia común entre los lectores.

En esta última parte se mencionan aspectos de la obra de Mimnermo que no se habían tocado antes, como la obra llamada Nanno. "I" pregunta sobre esto, pero el poeta griego no puede, o no quiere, dar una respuesta, lo que nos remitiría a las palabras de Wittgenstein, "Acerca de lo que no se puede hablar, es necesario guardar silencio":

\section{M: What are you digging for}

I: Nanno

M:

I: Who is this person this chasm this lost event

M:

I: Considerable ambiguity surrounds Athenaio's assertion that in old age you became enamored of a flute girl by this name

M:

I: Kallimachos talks about Nanno or "the big woman" as if it were an epic poem on the founding of Kolophon no one understands this reference

M:

(24)

La raya que pone la autora representa no sólo la negativa de Mimnermo a contestar, sino también la falta de respuestas que nos da la tradición textual, es decir, la laguna no es sólo de Mimnermo, también es de los papiros. En cambio, "I" es insistente y un tanto impaciente en su deseo por llenar los huecos: por ejemplo, repite la pregunta sobre quién es Nanno. Esta manera de querer leer la literatura buscando la confirmación en la vida real de lo que las palabras dicen ha sido una aproximación propia de los estudios clásicos, y que Carson critica con ironía en esta entrevista ${ }^{5}$ al querer buscar las respuestas a las interrogantes del texto en la vida personal del autor. Carson está

\footnotetext{
${ }^{5}$ No sólo en esta obra, también en "Essay on what I Think About Most", presenta esta crítica: "But as you know the chief aim of philology is to reduce all textual delight to an accident of history" (2009: 34).
} 
retratando un tipo de interpretación que durante mucho tiempo fue muy socorrida por los filólogos clásicos, lo cual también es algo muy natural en el arte mimético y en esta literatura tan distante en el tiempo a la que siempre queremos aprehender. Virginia Woolf, al hablar de su deseo por leer en griego, comparte esta inquietud:

Euripides was eaten by dogs; Aeschylus killed by a stone; Sappho leapt from a cliff. We know no more of them than that. We have their poetry, and that is all. But that is not, and perhaps never can be, wholly true. Pick up any play by Sophocles, read — Son of him who led our hosts at Troy of old, son of Agamemnon, and at once the mind begins to fashion itself surroundings (Woolf: 113).

Desde luego que la crítica moderna rechaza este tipo de lectura. Como dice Jan Mukarovsky, "la obra de arte es un signo, no un calco fiel del autor; y, por tanto, no ha de confundirse con él, aunque parezca expresar directamente sus propios sentimientos" (1966: 262). Rifaterre explica esta necesidad de encontrar este tipo de explicaciones gracias a la dificultad del texto que se está leyendo:

What the reader believes to be a feature of poetic language, a typical case of obscurity. This is when he starts rationalizing, finds himself unable to bridge the semantic gap inside the text's linearity, and so tries to bridge it outside of the text by completing the verbal sequence. He resorts to nonverbal items, such as details from the author's life, or to verbal items, scubas preset emblems or lore that is well established but not pertinent to the poem. All this just misguides the reader and compounds his difficulties. Thus, what makes the poem, what constitutes its message, has little to do with what it tells us or with the language it employs. It has everything to do with the given twists the mimetic codes out of shape by substituting its own structure for their structures (2014: 257).

Es decir, en la mente del lector sucede lo que Carson experimentó, uno se enamora a tal grado de una obra o autor que intenta desesperadamente descifrarlo por medios extratextuales, hurgar en el autor más profundamente hasta el punto de llegar a la fantasía.

Cuando Mimnermo dice Ah the perfect listener. I dreamed I would one day find her (Carson, 1995: 20), está diciendo algo parecido a lo que afirma Lázaro Carreter al explicar el lenguaje poético:

Porque hay un momento en el que el mensaje poético es por completo unívoco, al menos en el propósito: aquel en que el poeta escribe, con la imagen de un lector ideal ante los ojos, y en que se propone que ese receptor, próximo o distante en espacio y tiempo, haga suyos la significación y el sentido del poema. Este es su signo. Que lo consiga o no, depende ya de numerosas variables, entre las que figuran el grado de complejidad del cifrado, y las circunstancias biográficas y culturales de cada lector, que pueden hacerlo apto para la recepción de aquel mensaje, o completamente inepto (1990: 23). 


\section{$164 \square$ EL EROTISMO DE LA LECTURA ACADÉMICA. AMOR Y FILOLOGÍA}

Pero después advierte: "En el límite de la poesía hermética, el signo poético, el poema, es solipsista: mensaje dirigido a un destinatario que tal vez sólo existe en la mente del poeta, y que, en un caso teórico extremo, llega a ser él mismo" (24). ¿Acaso Anne Carson es la lectora ideal de Mimnermo, o esto es algo que la persona loquens quiere pensar? En las primeras dos partes pareciera que hay una comprensión total de Mimnermo. Lo entiende a tal punto que lo traduce y describe en un ensayo, pero en las entrevistas la conversación entre autor y lectora está rota, no hablan el mismo idioma, como dos amantes que se han distanciado. Quizá tuvo más éxito la lectora académica que la creativa, cuyo esfuerzo fue infértil.

Anne Carson está dramatizando la recepción que tradicionalmente se hace de los textos antiguos y el deseo por conocer al autor a toda costa y a la vez hace una especie de metáfora de la lectura y de la relación autor-lector, así como comenta diferentes acercamientos teóricos a la literatura. ${ }^{6}$ Es una fantasía erótica entre una lectora que desea saber más y un autor que no tiene más palabras que las de sus poemas. Aquí no hay interpretación y lecturas, sólo hay intentos vanos por querer desenterrar el significado oculto dentro de la obra. Ella hurga en los textos y en la tradición buscando información sobre Mimnermo que la pueda ayudar a comprender la obra. Al final, se vuelve una historia de amor no correspondido entre dos personas separadas por la historia, o por el tiempo.

A la brecha temporal que separa a la primera literatura de Occidente de la más reciente podemos atribuir la dificultad de comprensión de los clásicos y el deseo exacerbado por aprehender a Mimnermo. La poeta está externando su deseo de comunicarse con un autor griego haciendo uso de un recurso sólo disponible para los autores vivos: la entrevista. En el último retrato sexomental, Carson desafía las limitaciones impuestas por el tiempo. No sólo se expresa una posible fijación personal con la brevedad de la vida, sino que también dramatiza la dificultad de conocer a los clásicos por la distancia temporal que nos separa y divide.

Lo que tienen en común estos tres textos rotos son Carson y Mimnermo. Las diferentes voces de Carson tienen diferentes maneras de leer a Mimnermo. No hay un gran descubrimiento o una lectura diferente de Mimnermo: sólo retratos de la voz poética, académica y traductológica de Carson. Los tres retratos sexomentales culminan en una metáfora que se ve reflejada en el título: la relación erótica entre lectora y autor.

\footnotetext{
${ }^{6}$ Por ejemplo, critica formas un tanto ingenuas de hacer estudios literarios, concordando con Culler: "Criticism of the modern lyric, or modern criticism of the lyric in general, has challenged the romantic conception of lyric as the direct or sincere expression of emotion, but in so doing, it has allowed emphasis to fall on the importance of thinking of the speaker of lyric as a persona created by the poet rather than as the poet him- or herself. If the speaker is a persona, then interpretation of the poem is a characterization of the persona, as if he or she were a character in a novel, and of the situation in which the event of speech occurs. Though there is separation of the discourse of the lyric from the life of the poet as historical biographical figure, emphasis falls on the lyric as a representation of consciousness, and ideally of a drama of consciousness" (Culler, 2009: 71).
} 
Con los tres retratos abarca los tres géneros literarios. Es una exploración de una relación erótica entre una estudiosa y un autor. Hay diferentes maneras de leer y expresar la lectura que hacemos de un texto. Por medio de la traducción el lector absorbe y asimila las palabras del autor hasta que se convierten en parte de él. Escribir un ensayo sobre un texto requiere de gran sensibilidad lectora y perspicacia, y finalmente, se puede crear una obra nueva inspirada en nuestra pasión por algo viejo.

Juntar tres formas tan diversas sin realmente unirlas también es una representación de la poesía de Mimnermo. La obra de Carson está tan fragmentada como la de Mimnermo y la traducción simula la sensación que tiene el lector al momento de la lectura. Al final de la lectura de los tres géneros compartimos las inquietudes de la entrevistadora/Mimnermo "I wanted to know you"(26), y nuestro deseo, como el de Carson, queda insatisfecho. En otro libro, la poeta reconoce la dificultad de un encuentro perfecto: "In fact, neither reader nor writer nor lover achieves such consummation. The words we read and the words we write never say exactly what we mean. The people we love are never just as we desire them. The two symbols never perfectly match" (1998: 109).

\section{Obras citadas}

CAmPBell, David A., ed. y trad. 1990. Greek Lyric. Cambridge, Mass.: Loeb Classic Library / Harvard University Press.

CARson, Anne. 1998. Eros the Bittersweet. Urbana-Champaigne: Dalkey Archive. 1995. Plainwater. Essays and Poetry. Nueva York: Vintage.

1990. “'Just for the Thrill': Sychophantizing Aristotle's Poetics". Arion, 1,1. Pp. 142-154.

Culler, Jonathan. 2009. "Lyric, History, and Genre”. The Lyric Theory Reader: An Anthology. Baltimore: Johns Hopkins University Press. Pp. 63-77.

Dosse, Francoise. 2010. Gilles Deleuze \& Félix Guattari: Intersecting Lives. Nueva York: Columbia University Press.

Dubrow, Heather. 2014. "Lyric Forms". The Lyric Theory Reader: An Anthology. Baltimore: Johns Hopkins University Press. Pp. 112-118.

LÁzAro CARreter, Fernando. 1990. De poética y poéticas. Madrid: Cátedra.

MukARovsKy, Jan. 1966. Il significato dell'Estetica. Turín: Einaudi.

NorTh, Paul. 2015. The Yield. Kafka's Atheological Reformation. Stanford: Stanford University Press.

O’Dogherty Palmero, Isabel. 2011. Historias de imágenes y palabras: écfrasis narrativa y genérica en Un cabinet d'amateur de Georges Perec. México: UNAM, FFL. [Tesis de licenciatura.]

RIFATTERE, Michael. 2014. "The Poem's Significance”. The Lyric Theory Reader: An Anthology. Baltimore: Johns Hopkins University Press. Pp. 252-257. 
$166 \square$ EL EROTISMO DE LA LECTURA ACADÉMICA. AMOR Y FILOLOGÍA

Tschofen, Monique. 2013. "Drawing Out a New Image of Thought: Anne Carson's Radical Ekphrasis". Word \& Image, vol. 2, núm. 29. Pp. 233-243.

Vendler, Helen. 1997. Poems, Poets, Poetry. An Introduction and Anthology. Bedford, Boston: Books of St. Martin's Press.

Woolf, Virginia. 2013. The Common Reader. Vancouver: Read Books Ltd. 